\title{
SPECIES-ENVIRONMENT INTERACTION IN THE INTERIOR AND ON THE EDGE OF A SEMI-DECIDUOUS SEASONAL FOREST FRAGMENT
}

\author{
Salim Neto SC, *, Pezzopane JEM², da Silva GF², Ferreira RLC ${ }^{3}$, Martínez JRM ${ }^{4}$ \& Machuca MAH ${ }^{4}$ \\ IInstituto Estadual de Meio Ambiente e Recursos Hidricos, BR262, KM 0, Jardim América, Cariacica, ES, 29140-130, \\ Brasil \\ ${ }_{2}^{2}$ Departamento de Ciências Florestais e da Madeira, Universidade Federal do Espírito Santo, Av. Governador Lindenberg, \\ 316, Jerônimo Monteiro, ES, 29550-000, Brasil \\ 3Departamento de Ciências Florestais, Universidade Federal Rural de Pernambuco, Rua Manoel de Medeiros, s/n, Dois \\ Irmãos, Recife, PE, 52171-900, Brasil \\ ${ }^{4}$ Departamento de Ingeniería Forestal, Universidad de Córdoba, Edficio Leonardo da Vinci, Campus de Rabanales, \\ 14071-Córdoba, Spain
}

*calilsalimsalim@gmail.com

Submitted August 2020; accepted January 2021

\begin{abstract}
This study aimed at analysing the distribution of 40 tree species with the highest absolute density within a semi-deciduous seasonal forest fragment located in the municipality of Cachoeiro de Itapemirim, Espírito Santo, Brazil. There were 39 plots allocated for the study, consisting of 27 on the edge and 12 inside the fragment. The environmental variables used were: aluminium saturation, base saturation, soil moisture, leaf area index (LAI) and average slope. Canonical correspondence analysis using the CANOCO 2.1 program was applied to analyse the species-environment interactions on the edge and inside the fragment. Although the most striking heterogeneity in the fragment was related to the LAI and the land slope, the species showed the highest correlation with the soil characteristics (base saturation and aluminium saturation), suggesting that these species have generalist behaviour in relation to the availability of solar radiation in the environment and seek to establish their niche in the soil gradient. The results are helpful in increasing our understanding about the interactions between the species and the environmental variables involved in the study, enabling a more effective indication of them in forest restoration projects.
\end{abstract}

Keywords: Fragmentation, species distribution, forest restoration, forest ecology, reference ecosystem

\section{INTRODUCTION}

Undisturbed forests are characterised by low availability of light, high humidity, stable temperatures, low incidence of wind and almost continuous canopy coverage (Laurance et al. 2011). However, these conditions are changed during fragmentation, as an abrupt interface is created between the fragment and its surroundings. This interface is called edge and it causes edge effect that negatively affects species adapted to them (Fahrig 2003, Haddad et al. 2015, Fahrig et al. 2019).

The main edge effect is the alteration of the microclimate along the forest edge. The increased availability of solar radiation, air and soil temperature, wind speed and decrease in relative humidity are some examples of the consequences caused by the edge effect and these extend into the fragment (Murcia 1995, ArroyoRodríguez et al. 2017). A new microclimate condition at the edge opens space for species adapted to adverse conditions to establish themselves, thus changing the composition and spatial distribution of species in the fragment (Santo-Silva et al. 2016). In order to better understand the composition and distribution of species imposed by the fragmentation process, it is necessary to identify the main niches within a forest fragment in which the species show greater preemption to establish themselves (Brokaw \& Busing 2000, Johnson et al. 2017).

A categorical example of forest fragmentation is the Atlantic forest that is located on the east coast of South America and is a biome characterised by its great biodiversity and 
endemism. Its high fragmentation is promoted by activities related to deforestation for extracting wood and other forest products, agriculture, and urban and industrial expansion (Taubert et al. 2018). Currently, this biome is receiving attention and efforts to promote its recovery. Therefore, more effective methods and strategies must be applied to increase its forest cover. Associating phytosociology and floristics parameters with the study of environmental variables and their gradients can be a way to understand how species are established within a given forest fragment, and thereby enables recommendation of forestry ecosystem restoration and recovery strategies (Souza et al. 2017).

We hypothesise that the spatial distribution of the plant species of a fragment is correlated with environmental variables, which in turn are affected by the adverse effects arising from the edge effect. Given this context, the aim of this study was to analyse the spatial distribution of 40 tree species which showed the highest absolute density within a seasonal semi-deciduous forest fragment considering two distinct environments, namely, the edge and the interior of the forest fragment.

\section{MATERIALS AND METHODS}

\section{Study area}

The study was carried out at the Pacotuba National Forest (FLONA Pacotuba), a Sustainable Use Conservation Unit located $30 \mathrm{~km}$ from the municipality of Cachoeiro de Itapemirim, in the state of Espírito Santo, south-eastern Brazil (Figure 1). FLONA has an area of 450 ha and is part of the Atlantic Forest Domain. Its formation is characterised by submontane semi-deciduous seasonal forest (Garbin et al. 2017). The soil of the region is classified as Red Yellow Latosol Dystrophic. Coffee cultivation and pastures total about $76 \%$ of landuse in the entire region (Moreira 2009). The rainy season occurs in the months of October to April, with the months of November and December having the highest rainfall. The dry season runs from June to September. Average minimum temperature observed in the coldest month varies around 14 and $20^{\circ} \mathrm{C}$, and the average maximum temperature observed in the hottest month varies between 27 and $33^{\circ} \mathrm{C}$.

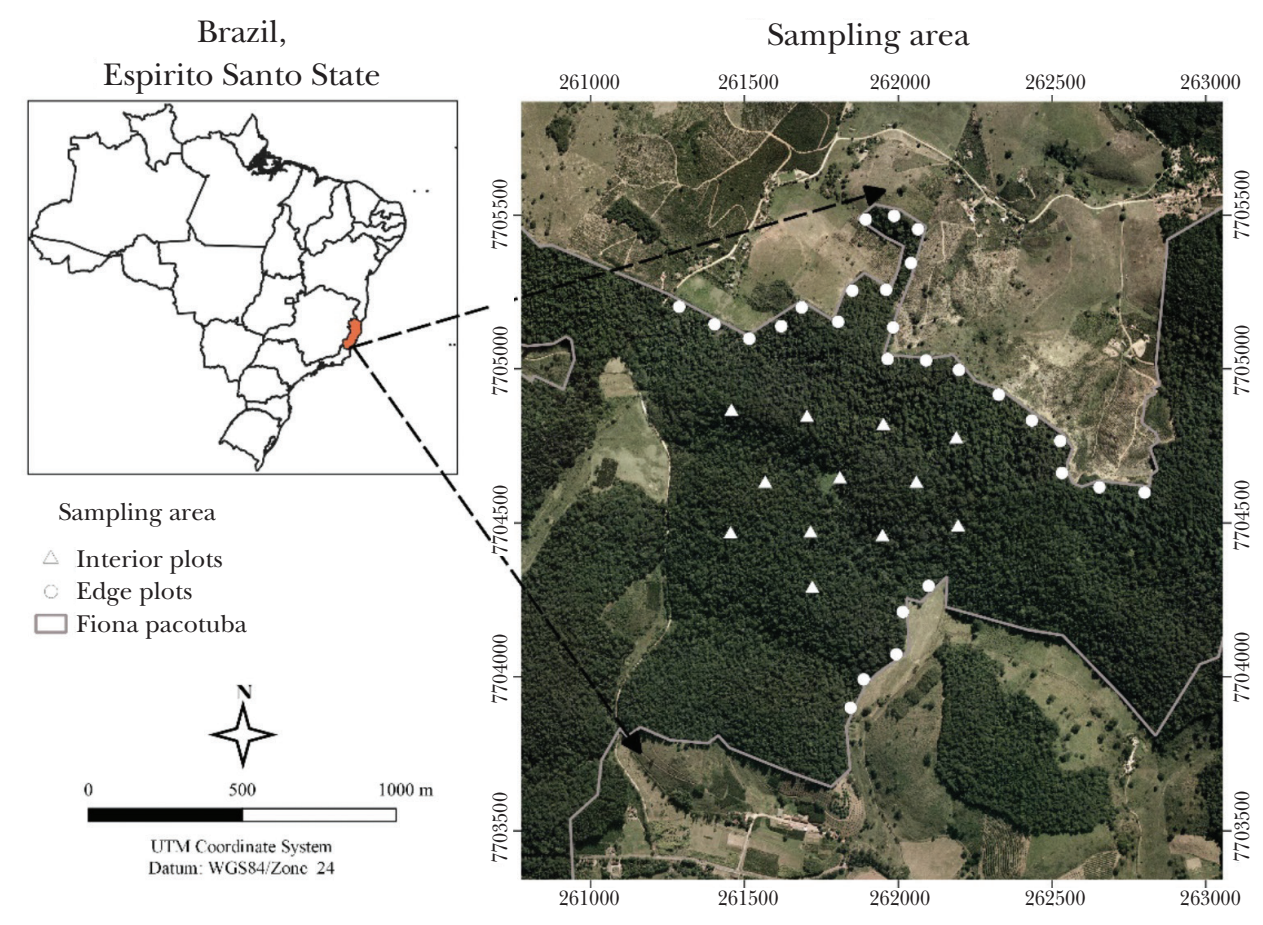

Figure 1 Aerial image of FLONA de Pacotuba, located in Espírito Santo State, Brazil, where 39 plots were set up (27 on the edge and 12 inside the fragment) 
An area of 119 ha was selected for sampling, as it was the most preserved area in FLONA. A total of 39 plots were allocated within this area which were systematically distributed in two blocks in order to sample and compare two different areas of the forest, namely, the edge area and the interior of the forest fragment. Of these plots, 27 plots of $10 \mathrm{~m} \times 30 \mathrm{~m}\left(300 \mathrm{~m}^{2}\right)$ were allocated along the edge of the fragment, making a total area of $0.81 \mathrm{ha}$, and the other 12 plots, measuring $40 \mathrm{~m} \times 50 \mathrm{~m}\left(2000 \mathrm{~m}^{2}\right)$ were allocated inside the fragment, making a total area of 2.4 ha.

\section{Species selection and environmental variables}

The 40 species which had the highest absolute density in the selected fragment were chosen to study the species-environment interaction (Table 1). These species were extracted from the phytosociological study developed by Moreira (2009) in the same area as the present work. For the development of the study, five environmental variables were measured in the plots. Three variables that express the edaphic conditions of the area, were aluminium saturation and base saturation, both of which were related to soil fertility, and soil moisture. Leaf area index (LAI) characterised the difference in canopy coverage between the two environments (i.e. edge and interior of the fragment) while the slope of the plots determined the heterogeneity of the topography. These environmental variables were measured in September 2010 and March 2011. The obtained results were subjected to the Student's $t$-test at $5 \%$ probability level to verify the difference between the edge environment and the interior of the fragment.

To characterise soil fertility, 20 samples were collected from each plot at perforation depths of $0-20 \mathrm{~cm}$. The collected soil was stored in bags identified for each plot and placed to dry naturally. After drying, the soil was sieved through a $10-\mathrm{mm}$ mesh, from which a fraction of each bag was removed and subjected to fertility analysis to determine the base saturation and aluminium saturation, according to the method by Donagema et. al. (2017). Soil moisture was determined using the gravimetric method. For this, soil was collected during the dry period (September 2010) using aluminium caps with lids. The soil was dried at $100^{\circ} \mathrm{C}$ until constant weight.
LAI was measured using two LAI-2050 sensors connected to LAI-2000 automatic data collectors at two different times, i.e. dry period (September 2010) and at the end of the rainy season (March 2011). The average slopes of all 39 plots in the study were determined using an inclinometer and measuring tape of $30 \mathrm{~m}$ to study the physiographic characteristics of the terrain.

\section{Study of the species-environment interaction}

A matrix of species abundance per plot was structured with data on absolute density of the 40 species involved in the study (Table 1 ). The matrix was subjected to canonical correspondence analysis (CCA) together with a structured matrix from data on environmental variables (Ter Braak 1986). Following this, two more canonical correspondence analyses (CCAs) were carried out for better understanding of the environmental preferences of each species. This involved separating the 40 species into three distinct groups according to the proportion in relation to absolute density between the edge environment and the interior of the fragment (Figure 2). The first group was represented by species which had at least $70 \%$ of their absolute density found at the fragment edge (11 species). The second group was formed by the species which presented at least $70 \%$ of their absolute density inside the fragment (11 species). Finally, the third group was formed by the other 18 species which did not present an absolute density placed in any of the studied environments, meaning those species which did not proportionally present an absolute density greater than or equal to $70 \%$ either for the edge environment or the forest fragment interior.

The first CCA was related to the 22 species which were in the first two groups, meaning those which obtained at least $70 \%$ of their absolute density observed in one of the studied environments (edge or interior) while the second CCA involved the third group. The three CCAs were performed using the CANOCO 2.1 program. As recommended by Ter Braak and Verdonschot (1995), the abundance values were transformed using the expression $\ln (\mathrm{a}+1)$, where $\ln$ was the Neperian logarithm. This reduced discrepancy of variances observed between densities of the species, which were common in studies involving ecological data. The Monte Carlo permutation test was applied $(p=0.01)$ to determine the significance of the main ordering axis. 
Table 1 List of the 40 species with the highest density in the fragment

\begin{tabular}{|c|c|c|c|c|c|}
\hline \multirow{2}{*}{ Species } & \multirow{2}{*}{$\mathrm{N}$} & \multicolumn{2}{|c|}{ Environment } & \multirow{2}{*}{ EG } & \multirow{2}{*}{$\begin{array}{l}\text { CCA } \\
\text { Code }\end{array}$} \\
\hline & & N Interior & N Edge & & \\
\hline Senefeldera verticillata & 440.5 & 555.8 & 98.7 & LS & Sp1 \\
\hline Actinostemon estrellensis & 307.1 & 393.7 & 50.6 & LS & Sp2 \\
\hline Neoraputia alba & 58.2 & 64.1 & 40.7 & LS & Sp3 \\
\hline Astronium concinnum & 53.8 & 41.6 & 90.1 & IS & $\mathrm{Sp} 4$ \\
\hline Pseudopiptadenia contorta & 51.0 & 17.5 & 150.6 & PI & Sp5 \\
\hline Chrysophyllum lucentifolium subsp. lucentifolium & 43.9 & 48.3 & 30.8 & LS & Sp6 \\
\hline Astronium graveolens & 35.5 & 12.1 & 104.9 & IS & Sp7 \\
\hline Virola gardneri & 35.2 & 44.1 & 8.6 & LS & Sp8 \\
\hline Anadenanthera peregrina & 34.8 & 37.9 & 25.9 & IS & Sp9 \\
\hline Casearia sp. 1 & 19.9 & 26.6 & 0 & $\mathrm{NC}$ & Sp10 \\
\hline Rinorea bahiensis & 19.6 & 26.2 & 0 & LS & Sp11 \\
\hline Ramisia brasiliensis & 16.2 & 17.5 & 12.3 & PI & Sp12 \\
\hline Carpotroche brasiliensis & 13.0 & 7.5 & 29.6 & LS & Sp13 \\
\hline Myroxylon peruiferum & 12.7 & 16.2 & 2.4 & LS & Sp14 \\
\hline Ecclinusa ramiflora & 11.5 & 11.2 & 12.3 & LS & Sp15 \\
\hline Sorocea guilleminiana & 11.5 & 13.7 & 4.9 & LS & Sp16 \\
\hline Guapira noxia & 10.5 & 10.0 & 12.3 & IS & Sp17 \\
\hline Pterygota brasiliensis & 10.2 & 6.6 & 20.9 & $\mathrm{NC}$ & Sp18 \\
\hline Guarea guidonia & 9.9 & 5.0 & 24.6 & IS & Sp19 \\
\hline Macrothumia kuhlmannii & 9.6 & 11.2 & 4.9 & $\mathrm{NC}$ & Sp20 \\
\hline Copaifera lucens & 9.6 & 10.0 & 8.6 & IS & Sp21 \\
\hline Micropholis gardneriana & 9.3 & 6.6 & 17.2 & LS & Sp22 \\
\hline Marlierea tomentosa & 9.0 & 12.1 & 0 & $\mathrm{NC}$ & Sp23 \\
\hline Guapira opposita & 8.7 & 4.5 & 20.9 & IS & Sp24 \\
\hline Trichilia pallens & 8.7 & 7.5 & 12.3 & IS & Sp25 \\
\hline Casearia sp. & 8.1 & 3.3 & 22.2 & $\mathrm{NC}$ & Sp26 \\
\hline Miconia sp. & 8.1 & 0 & 32.1 & PI & Sp27 \\
\hline Pouteria filipes & 7.1 & 4.9 & 7.9 & LS & Sp28 \\
\hline Trichilia lepidota subsp. schumanniana & 6.8 & 3.7 & 7.9 & LS & Sp29 \\
\hline Parapiptadenia pterosperma & 6.8 & 2.5 & 19.7 & IS & Sp30 \\
\hline Alseis sp.1 & 6.8 & 8.7 & 1.2 & $\mathrm{NC}$ & Sp31 \\
\hline Virola oleifera & 6.8 & 7.9 & 3.7 & LS & Sp32 \\
\hline Eugenia cf. tinguyensis & 6.8 & 8.3 & 2.4 & CL & Sp33 \\
\hline Trichilia sp. & 6.8 & 6.2 & 8.6 & $\mathrm{NC}$ & Sp34 \\
\hline Clarisia racemosa & 6.2 & 6.2 & 6.1 & LS & Sp35 \\
\hline Ziziphus glaziovii & 6.2 & 6.2 & 6.1 & LS & Sp36 \\
\hline Abarema limae sp. nov & 6.2 & 8.3 & 0 & $\mathrm{NC}$ & Sp37 \\
\hline Oxandra nitida & 5.9 & 6.6 & 3.7 & $\mathrm{NC}$ & Sp38 \\
\hline Couratari asterotricha & 5.9 & 6.2 & 4.9 & IS & Sp39 \\
\hline Goniorrhachis marginata & 5.6 & 0 & 22.2 & LS & Sp40 \\
\hline
\end{tabular}

$\mathrm{N}=$ number of individuals $\mathrm{ha}^{-1}$ in the fragment, $\mathrm{N}$ Interior $=$ number of individuals $\mathrm{ha}^{-1}$ in the interior, $\mathrm{N}$ Edge $=$ number of individuals ha ${ }^{-1}$ on the edge, $\mathrm{EG}=$ ecological group, $\mathrm{PI}=$ pioneers, $\mathrm{IS}=$ initial secondary, $\mathrm{LS}=$ late secondary, $\mathrm{CL}=$ climax, $\mathrm{SC}=$ no characterisation, $\mathrm{CCA}$ code $=$ species code in the CCA diagram; source of phytosociological data: Moreira (2009)

\section{RESULTS}

The results obtained in the 39 plots at the edge and interior of the fragment for the environmental variables involved in the study are shown in Table 2. The forest fragment showed significant differences in LAI and slope following the Student $t$ test between the edge and 
the interior. However, for the edaphic variables, there was no significant difference between the two environments.

The results of the correlation matrix resulting from the CCA with the 40 species and the five environmental variables, are shown in Table 3. The first two ordering axes explained $64.5 \%$ of the observed variance and the results were statistically significant according to the Monte Carlo test. The Monte Carlo test applied to the first two axes of CCA ordering showed that the correlation between environmental variables and the species involved in the study was statistically significant $(p=0.002)$. Figure 3 shows the distribution of the 40 species in relation to the environmental variables.

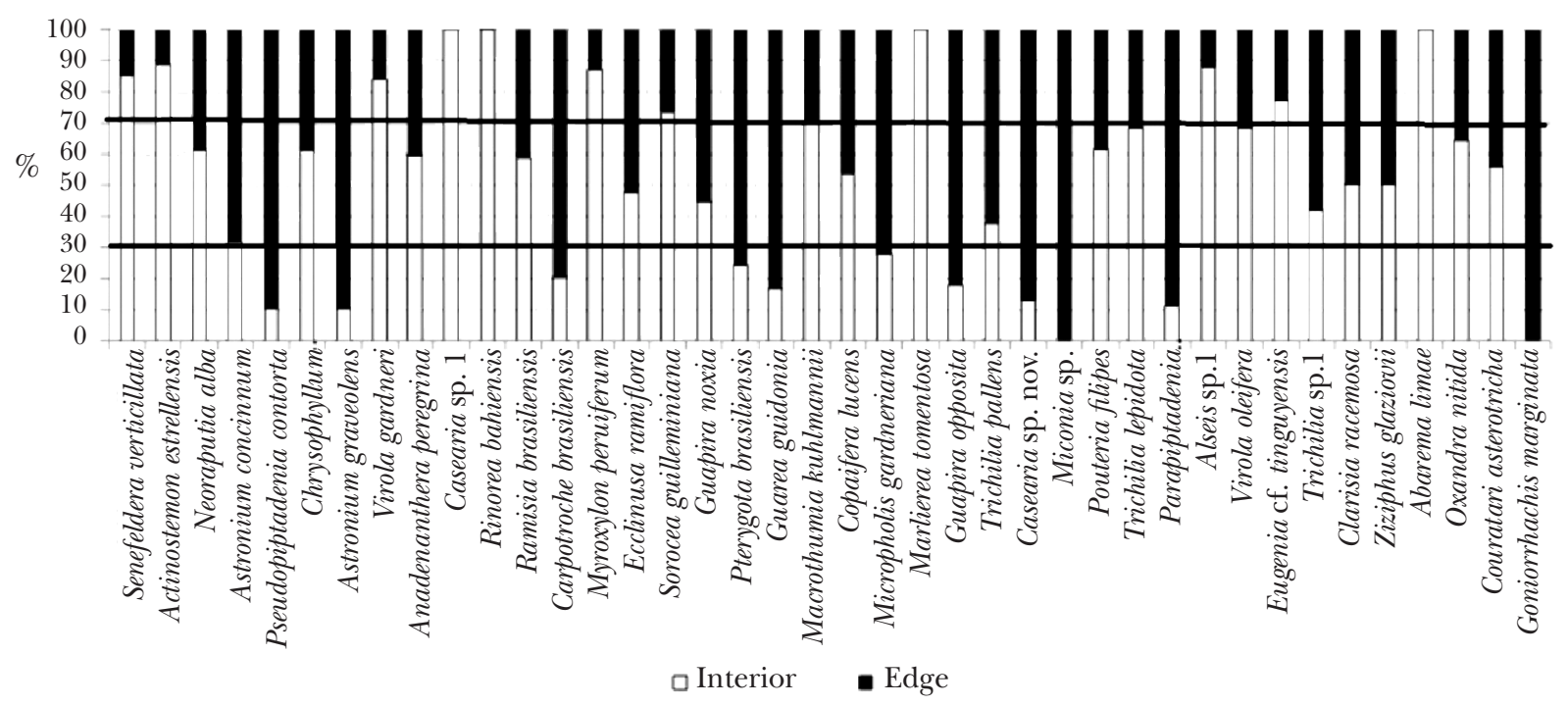

Figure 2 Proportion of absolute density between the fragment edge and the interior environment for the 40 species which showed the highest density; source of phytosociological data: Moreira (2009)

Table 2 Values of the five variables for the edge and interior environment of the fragment

\begin{tabular}{lcccccc}
\hline Plot & $\begin{array}{c}\text { Slope } \\
(\boldsymbol{\%})\end{array}$ & $\begin{array}{c}\text { Base saturation } \\
(\boldsymbol{\%})\end{array}$ & $\begin{array}{c}\text { Al saturation } \\
(\boldsymbol{\%})\end{array}$ & $\begin{array}{c}\text { Soil moisture } \\
\text { 2010/SEP }(\boldsymbol{\%})\end{array}$ & $\begin{array}{c}\text { LAI } \\
\text { 2010/SEP }\end{array}$ & $\begin{array}{c}\text { LAI } \\
\text { 2011/MAR }\end{array}$ \\
\hline Edge & $10.1^{*}$ & 45.2 & 23.4 & 18.5 & $2.8^{*}$ & $4.1^{*}$ \\
Interior & $28.8^{*}$ & 40.8 & 24.1 & 18.7 & $3.5^{*}$ & $5.3^{*}$ \\
p value & 0.003 & 0.30 & 0.94 & 0.95 & 0.003 & 0.000006 \\
\hline
\end{tabular}

Slope $=$ average slope, $\mathrm{LAI}=$ leaf area index; $*=$ statistically significant difference by Student's $t$-test at the $5 \%$ probability level

Table 3 Correlation matrix resulting from the analysis of canonical correspondence between the first two ordering axes based on data collected in FLONA Pacotuba, Brazil

\begin{tabular}{lcc}
\hline & Eigenvalue & Accumulated percentage \\
\hline $1^{\text {st }}$ axis & 0.269 & 36.4 \\
$2^{\text {nd }}$ axis & 0.208 & 64.5 \\
\hline \multicolumn{3}{r}{ Monte Carlo test } \\
\hline Trait & 0.740 & \\
$\mathrm{~F}$ & 3.251 & \\
$\mathrm{P}$ value $\mathrm{P}$ & 0.0020 & \\
\hline
\end{tabular}


The results of the second CCA for the two groups of species which presented a density proportion greater than or equal to $70 \%$ at the edge or inside the fragment are shown in Table 4. The first two ordering axes explained $71.8 \%$ of the observed variance and the result was statistically significant by the Monte Carlo test $(p=0.002)$. The last CCA involved the third group of species which did not present an absolute density in proportion of at least $70 \%$ in one of the environments. The first two ordering axes explained $72.9 \%$ of the observed variance and the results were statistically significant according to the Monte Carlo test $(p=0.002)$ (Table 5).
The preference for the edge environment or the interior of the fragment became visible when analysing the diagram generated by the CCA which considered the first two groups of species (Figure 4). The species located at the top of the diagram refer to the group which shows at least $70 \%$ of its density observed at the edge, while species located at the bottom refer to the group observed within the fragment. On the other hand, the distribution of species in the third group, which are those that do not show densities greater than or equal to $70 \%$ for one of the two environments in relation to the environmental variables can be observed in Figure 5.

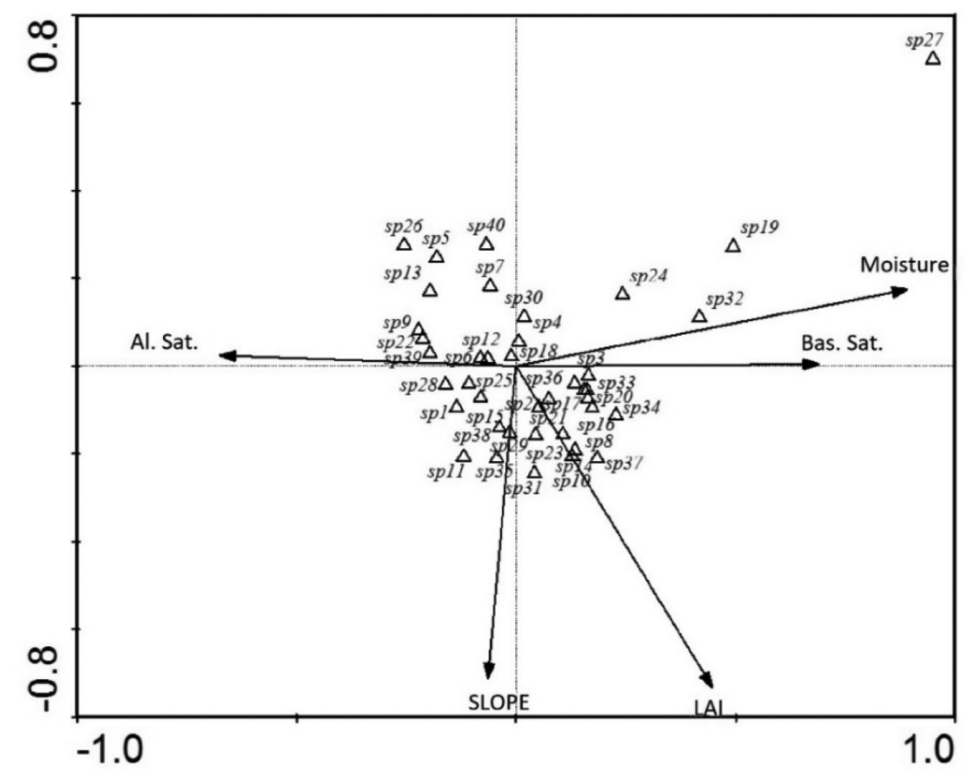

Figure 3 Ordering diagram obtained from the analysis of canonical correspondence, representing the distribution of 40 species of greater density in the studied fragment and five environmental variables ( $\mathrm{Al}$ saturation, base saturation, LAI (leaf area index), slope and soil moisture), sampled in 39 plots in Pacotuba FLONA in Cachoeiro de Itapemirim-ES, Brazil

Table 4 Correlation matrix resulting from the analysis of canonical correspondence considering the two groups of species which presented at least $70 \%$ of absolute density in one of the environments (edge or interior)

\begin{tabular}{lcc}
\hline & Eigenvalue & Accumulated percentage \\
\hline $1^{\text {st }}$ axis & 0.321 & 38.1 \\
$2^{\text {nd }}$ axis & 0.284 & 71.8 \\
\hline \multicolumn{2}{c}{ Monte Carlo test } \\
\hline Trait & 0.844 & \\
$\mathrm{~F}$ & 3.884 & \\
$\mathrm{p}$ value & 0.0020 & \\
\hline
\end{tabular}


Table 5 Correlation matrix resulting from the analysis of canonical correspondence considering the groups of species which did not present at least $70 \%$ of absolute density in one of the environments (edge or interior)

\begin{tabular}{lcc}
\hline & Eigenvalue & Accumulated percentage \\
\hline $1^{\text {st }}$ axis & 0.260 & 53.9 \\
$2^{\text {nd }}$ axis & 0.091 & 72.9 \\
\hline \multicolumn{2}{c}{ Monte Carlo test } & \\
\hline Trait & 0.483 & \\
$\mathrm{~F}$ & 3.139 & \\
$\mathrm{p}$ value & 0.0020 & \\
\hline
\end{tabular}

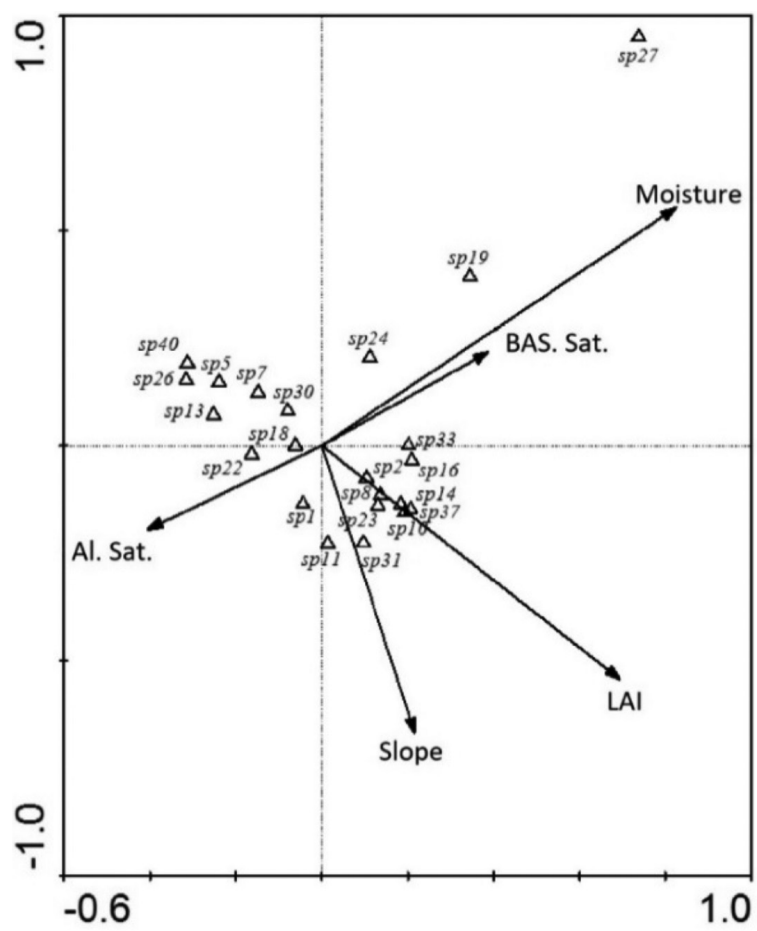

Figure 4 Ordering diagram obtained from the analysis of canonical correspondence representing the distribution of the 22 species which presented at least $70 \%$ of absolute density in one of the environments (edge or interior) and five environmental variables (Al saturation, base saturation, LAI (leaf area index), slope and soil moisture)

\section{DISCUSSION}

\section{Characterisation of fragment from} environmental variables

The forest fragment presented a greater slope in its interior, while the edge had a flatter topography and was located in the lower levels. This physiographic characteristic of the fragment may explain the lack of significant difference between edge and interior for the edaphic variables (Table 2) (Zhang et al. 2016). Edge environment was more affected by adverse effects from the matrix (edge effect), and with that, it was expected that this environment would present a drier and poorer nutrient soil when compared with the interior of the fragment. Its relatively flat physiography probably influenced the results for the soil (base saturation, aluminium saturation and humidity) to approach the values found inside the fragment.

Thus, in the present study, there was a clear niche difference from the edge effect caused by fragmentation process. This result is similar to that found by Magnago et al. (2015) in a study in the Brazilian Atlantic Forest. The niche difference plays an important role in 


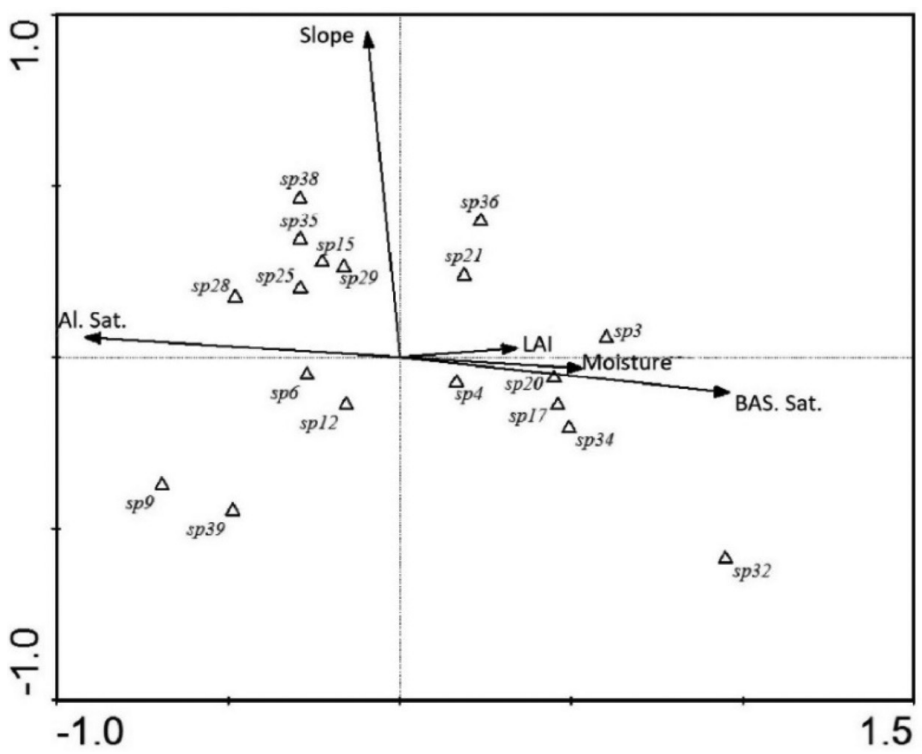

Figure 5 Ordering diagram obtained from canonical correspondence analysis representing the distribution of the 18 species which did not show preference for one of the environments and five environmental variables (Al saturation, base saturation, LAI (leaf area index), slope and soil moisture)

maintaining biodiversity and in understanding the coexistence of species in a tropical forest (Johnson et al. 2017). The influence of the niche difference becomes more pronounced in the young stages of plants such as seedlings (Baldeck et al. 2013), and their survival determines the composition of species in the forest (Poorter 2007).

Pioneer species are quick to establish at the edge of the fragment because of increased light. On the other hand, secondary late and climax species are largely distributed within the fragment, which has a more shaded environment (Tabarelli et al. 2008, Joly et al. 2014). In fact, in this study, among the 40 species with the highest absolute density, 22 species were observed in one of the environments (edge or interior). Of the 11 species found at the edge, 6 were considered pioneer or secondary initial. From the 11 species found in the interior, 6 were considered late secondary (Moreira 2009; Table 1).

\section{Environment and species interaction for forest restoration}

The greater correlation with the edaphic variables in the first axis (-0.565 for aluminium saturation, 0.576 for base saturation and 0.745 for soil moisture), indicated that the characteristics referring to the soil in the studied fragment had greater influence on the species distribution compared to the availability of solar radiation and the terrain topography. This lack of difference in relation to the canopy cover was also observed by other authors, e.g. Lieberman et al. (1995) and Chase and Myers (2011), corroborating the present findings that forest species are generalists regarding the availability of solar radiation in the environment.

Considering the variables included in the study, although there was a marked environmental difference between the edge and the interior of the forest fragment related to the average slope and LAI, we observed that the species generally competed according to edaphic gradient to establish themselves in view of the grouping around these variables. The preference for the edge environment or the interior of fragment became clear only when observing the results obtained by the CCA that took into account the three groups of species divided according to the proportion between the absolute density found at the edge or in the fragment. In assessing the species distribution between the first two groups (i.e. species that presented at least $70 \%$ of their density in one of the environments), we observed that the species in the interior were less dispersed among themselves. This indicated that the interior of the fragment provided conditions which resulted in greater competition for light when compared to the edge of the fragment. This meant that as the edge of the fragment presented 
little restriction regarding solar radiation availability, it was inferred that the species tended to disperse along the edaphic gradient, seeking niches which were favourable to its development in this gradient.

If a reference ecosystem brings information about the environmental variables that drove the establishment of the species that make it up, it is worth using this information to improve species selection in forest restoration projects. These projects always aim for greater precision and lower mortality of seedlings planted in the field. It could be seen in Figure 4 that Pseudopiptadenia contorta (Sp5), Astronium graveolens ( $\mathrm{Sp} 4)$, Carpotroche brasiliensis (Sp13), Pterygota brasiliensis (Sp18), Micropholis gardneriana (Sp22), Casearia sp.(Sp26), Parapiptadenia pterosperma (Sp30) and Goniorrhachis marginata (Sp40) were affected by aluminium saturation. These species were less demanding in terms of soil fertility and moisture, and could be used for recovery of severely degraded areas. Aluminium saturation was also reported to affect the distribution of species in tropical rainforest (Ferreira-Júnior et al. 2007, Gonçalves et al. 2011). Gonçalves et al. (2011) found P. contorta and Casearia sp. in regions of low fertility with high soil acidity in Mariana, Minas Gerais, Brazil and suggested that these two species would be suitable for planting on slopes and hill tops.

Due to the accentuated weathering, most tropical soils have low fertility, with high levels of iron and aluminium oxides and low $\mathrm{pH}$, characteristics that are unfavorable for the development of plants (Vitousek \& Sanford 1986). Although toxicity can occur, the presence of aluminium in acidic soils can benefit species that have tolerance to this metal, e.g. stimulation of root growth, improvement in nutrient absorption and prevention against biotic and abiotic stresses (Bojórquez-Quintal et al. 2017). These authors state that the mechanisms of aluminium tolerance occur in two ways, namely, (1) by exclusion and resistance which prevent the entry of aluminium into the cells, and (2) by internal tolerance to the cell, compartmentalising aluminium in the vacuole and, thus, inhibiting its toxicity. Future work should investigate which mechanism of tolerance to aluminium prevail in the species found in these environments, where the presence of this metal is substantially high. Guarea guidonia (Sp19), Guapira opposita (Sp24) and Miconia sp. (Sp27) occurred in more humid locations that had high nutrients in the soil, and, thus, suitable for enrichment planting.

The diagram generated from the CCA (Figure 4) which was related to the third group of species, LAI and soil moisture, had very little influence on the species in this group as seen by the size of the vectors, which portrayed the generalist behaviour of these species mainly in relation to light availability in the environment. These species showed an indifferent behaviour in relation to the LAI, and consequently, to the availability of solar radiation in the environment. They were dispersed along the edaphic gradient, seeking the most favourable conditions to establish themselves in these variables.

Ecclinusa ramiflora (Sp15), Trichilia pallens (Sp25), Pouteria Filipe (Sp28), Trichilia lepidota (Sp29), Clarisia racemosa (Sp35) and Oxandra nitida (Sp38) were present in the fragment in more open, rugged places with little humidity and availability of nutrients. Therefore, these species are recommended for planting at degraded areas, especially in rugged places and on soil having high acidity. Copaifera lucens (Sp21) and Ziziphus glaziovii (Sp36) were affected by slope and LAI, indicating that these species can grow well on rugged topography and with low solar radiation incidence. This makes these species suitable for slope enrichment in recovery process.

Chrysophyllum lucentifolium (Sp6) and Ramisia brasiliensis ( $\mathrm{Sp} 12)$ also demonstrated little demand regarding the availability of nutrients in the soil. However, these species establish better in places with less inclination in the fragment, and therefore, are suggested for lower sites. Neoraputia alba (Sp3), Astronium concinnum (Sp4), Guapira noxia (Sp17), Macrothumia kuhlmannii (Sp20) and Trichilia sp. (Sp34) have greater correlation with base saturation, soil moisture and LAI. These species had low tolerance to solar radiation and grew in places with fertile and moist soils.

Virola oleifera (Sp32), Anadenanthera peregrina (Sp9) and Couratari asterotricha (Sp39) were found in regions with little slope. Anadenanthera peregrina and C. asterotricha were less demanding in terms of soil fertility, unlike $V$. oleifera which was influenced by base saturation. It was suggested that the niche difference between these three species in the present study was associated with the physiographic position of the terrain. While $V$. oleifera grew at lower places in 
the land with high moisture and soil fertility, $A$. peregrina and C. asterotricha preferred flat hill-top regions with low fertility and soil moisture.

The distribution of the species shown here could be related to the role played by the differentiated relief between the edge and the interior of the fragment, where the former had a softer relief while the latter, a sloping relief. In the CCA diagrams, it was observed that the size of the arrow for slope hardly changed (Figures 4 and 5), suggesting that slope had great influence in relation to the availability of the rest of the variables (LAI, moisture, aluminium saturation and base saturation) in the study. This role relief in promoting environmental heterogeneity within a forest had already been studied by several authors (Comita \& Engelbrecht 2009, Wolf et al. 2012, de Souza et al. 2013). On a local scale, topography has been considered as the most important variable in spatial distribution and structure of tropical forests, because it corresponds to changes in soil properties, particularly in the water regime and fertility (Rodrigues et al. 2007). Our results corroborated with that of Lan et al. (2011), whereby working in a tropical forest in China, these authors found that the topography had strong influence on the distribution of species.

\section{CONCLUSIONS}

The studied forest fragment play a relevant role in the availability of edaphic resources and solar radiation and, consequently, the distribution of the species along the fragment. Of the 40 species studied, using CCA, it was possible to separate the species into different groups. This was done by analysing their distribution in the fragment in relation to the environmental variables involved in the study and covering the border area and the interior of the fragment. Species at the edge of the fragment or those that were considered generalists in terms of the availability of light in the environment, compete for the edaphic gradient (fertility and moisture) to establish their niche. Species inside the fragment were strongly influenced by LAI, indicating that they were intolerant to the availability of light in the environment.

Results obtained in this study will improve our understanding of the niches in which species occupy. This information will be useful for future forest restoration projects. However, the interaction between environmental variables and species distribution in reference to forest ecosystems must be studied continually. It is also necessary to establish long-term studies that will confirm if information collected in reference ecosystems should be used in forest restoration projects. This way, we can improve the selection of species to be planted and, ultimately, avoid wastes due failures in forest restoration.

\section{REFERENGES}

Arroyo-Rodríguez V, SAldana-VazQuez RA, Fahrig L et al. 2017. Does forest fragmentation cause an increase in forest temperature? Ecological Research 32: 81-88.

Baldeck CA, Harms KE, Yavitt JB Et al. 2013. Habitat filtering across tree life stages in tropical forest communities. Proceedings of the Royal Society B: Biological Sciences 280: 20130548. https://doi. org/10.1098/rspb.2013.0548

Bojórquez-Quintal E, Escalante-Magaña C, EchevarríaMachado \& Martínez-Estévez M. 2017. Aluminum, a friend or foe of higher plants in acid soils. Frontiers in Plant Science 8: 1767. https://doi.org/10.3389/ fpls.2017.01767

BrokAW N \& Busing RT. 2000. Niche versus chance and tree diversity in forest gaps. Trends in Ecology E Evolution 15: 183-188.

Chase JM \& Myers JA. 2011. Disentangling the importance of ecological niches from stochastic processes across scales. Philosophical Transactions of the Royal Society B: Biological Sciences 366: 2351-2363.

Comita LS \& Engelbrecht BMJ. 2009 Seasonal and spatial variation in water availability drive habitat associations in a tropical forest. Ecology 90: 27552765.

De Souza PB, Meira Neto JAA \& Souza AL. 2013. Diversidade florística e estrutura fitossociológica de um gradiente topográfico em floresta estacional semidecidual submontana, MG. Cerne 19: 489-499.

Donagema GK, De Campos DB, Calderano SB et al. 2017. Manual de Métodos de Análise de Solo. Third edition. Embrapa Solos, Rio de Janeiro.

FAHRIG L. 2003. Effects of habitat fragmentation on biodiversity. Annual Review of Ecology, Evolution, and Systematics 34: 487-515.

Fahrig L, Arroyo-Rodríguez V, Bennett JR et al. 2019. Is habitat fragmentation bad for biodiversity? Biological Conservation 230: 179-186.

Ferreira-Júnior W, Silva A, Schaefer C et al. 2007. Influence of soils and topographic gradients on tree species distribution in a Brazilian Atlantic tropical semideciduous forest. Edinburgh Journal of Botany 64: 137-157. 10.1017/S0960428607000832

Garbin ML, Saiter FZ, Carrijo TT et al. 2017. Breve histórico e classificação da vegetação capixaba. Rodriguésia 68: 1883-1894.

Gonçalves IDS, Dias HCT, Martins SV ET AL. 2011. Influence of soil factors on the floristic variations of a section of riparian forest in the River Gualaxo do Norte, Mariana, MG. Revista Árvore 35: 1235-1243. 
Haddad NM, Brudvig LA, Clobert J et al. 2015. Habitat fragmentation and its lasting impact on earth's ecosystems. Science Advances 1: e1500052.

Johnson DJ, Condit R, Hubbell SP \& Comita LS. 2017. Abiotic niche partitioning and negative density dependence drive tree seedling survival in a tropical forest. Proceedings of the Royal Society B: Biological Sciences 284: 20172210. http:/ /dx.doi.org/10.1098/ rspb.2017.2210

Joly CA, Metzger JP \& Tabarelli M. 2014. Experiences from the Brazilian Atlantic Forest: ecological findings and conservation initiatives. New Phytologist 204: 459-473. doi: 10.1111/nph.12989

Lan G, Hu Y, CaO M \& Zhu H. 2011. Topography related spatial distribution of dominant tree species in a tropical seasonal rain Forest in China. Forest Ecology and Management. 262: 1507-1503. https://doi. org/10.1016/J.FORECO.2011.06.052

Laurance WF, Camargo JL, Luizão RC et al. 2011. The fate of Amazonian forest fragments: a 32-year investigation. Biological conservation 144: 56-67.

Lieberman M, Lieberman D, Peralta R \& Hartshorn G. 1995. Canopy closure and the distribution of tropical forest tree species at La Selva, Costa Rica. Journal of Tropical Ecology 11: 161-177. doi:10.1017/ S0266467400008609

Magnago LFS, Rocha MF, Meyer L et al. 2015. Microclimatic conditions at forest edges have significant impacts on vegetation structure in large Atlantic forest fragments. Biodiversity and Conservation 24: 23052318.

Moreira LN. 2009. Fitossociologia em ambiente de borda de fragmento de floresta estacional semidecidual. MSc dissertation, Universidade Federal do Espírito Santo, Vitória.

Murcia C. 1995. Edge effects in fragmented forests: implications for conservation. Trends in Ecology $\mathcal{F}^{2}$ Evolution 10: 58-62.

Poorter L. 2007. Are species adapted to their regeneration niche, adult niche, or both?. The American Naturalist 169: 433-442. doi: 10.1086/512045
Rodrigues La, De Carvalho DA, De Oliveira Filho AT \& Curi N. 2007. Efeitos de solos e topografia sobre a distribuição de espécies arbóreas em um fragmento de floresta estacional semidecidual, em Luminárias, MG. Revista Árvore 31. https://doi.org/10.1590/ S0100-67622007000100004

Santo-Silva EE, Almeida WR, Tabarelli M \& Peres CA. 2016. Habitat fragmentation and the future structure of tree assemblages in a fragmented Atlantic forest landscape. Plant Ecology 217: 1129-1140. doi:10.1007/ s11258-016-0638-1

Souza RF, Machado SA, Galvão F \& Filho AF. 2017. Effect of environmental variables in the distribution of tree species in the iguaçu national park. Revista Árvore 41. https://doi.org/10.1590/1806-90882017000600009

Tabarelli M, Lopes AV \& Peres CA. 2008. Edge-effects drive tropical forest fragments towards an earlysuccessional system. Biotropica 40: 657-661.

Taubert F, Fischer R, Groeneveld J et al. 2018. Global patterns of tropical forest fragmentation. Nature 554: 519-522. doi: 10.1038/nature25508

TER BraAk CJ. 1986. Canonical correspondence analysis: a new eigenvector technique for multivariate direct gradient analysis. Ecology 67: 1167-1179.

Ter Braak CJ \& Verdonschot PF. 1995. Canonical correspondence analysis and related multivariate methods in aquatic ecology. Aquatic Sciences 57: 255-289.

Vitousek PM \& SANFord RL. 1986. Nutrient cycling in moist tropical forest. Annual Review of Ecology and Systematics 17: 137-167.

Wolf JA, Fricker GA, Meyer V, Hubbell SP, Gillespie TW \& SAATCHI SS. 2012. Plant species richness is associated with canopy height and topography in a neotropical. Remote Sens 4: 4010-4021. doi:10. 3390/rs4124010

Zhang C, Li X, Chen L, Xie G, Liu C \& Pei S. 2016. Effects of topographical and edaphic factors on tree community structure and diversity of subtropical mountain forests in the Lower Lancang River Basin. Forests 7: 222. https://doi.org/10.3390/f7100222 